\title{
Numerical Taxonomy Study of the Taxonomic Position of Nocardia rubra Reclassified as Gordona lentifragmenta Tsukamura nom.nov.
}

\author{
M. TSUKAMURA, S. MIZUNO, AND H. MURATA \\ The National Sanatorium Chubu Chest Hospital, Obu, Aichi, Japan 474
}

\begin{abstract}
A numerical classification using a total of 105 characters showed that Gordona strains together with rhodochrous strains formed a cluster, suggesting that these organisms belong to the same genus. Nocardia rubra strains were incorporated into this cluster. Nocardia rubra has accordingly been transferred to the genus Gordona. As Gordona rubra would be a junior homonym of the name of a species already assigned to that genus and subsequently shown to be identical with Gordona rubropertincta, Gordona lentifragmenta Tsukamura nom.nov. has been proposed for the strains originally known under the name Nocardia rubra.
\end{abstract}

Previously, Tsukamura (20) gathered nocardiae having several specific names, Nocardia rubra, $N$. lutea, $N$. globerula, $N$. minima, $N$. polychromogenes, $N$. erythropolis, etc., into the species Nocardia rubra. When later (22) he proposed the genus Gordona for slightly acidfast organisms lacking mycelium, $N$. rubra was found to resemble considerably Gordona organisms but was not included at that time in the genus Gordona, as it showed fragmenting mycelium. Later Tsukamura (23) transferred the rhodochrous group to the genus Gordona as Gordona rhodochroa. The presence of $N$. rubra hindered clearcut separation of Gordona from Nocardia. Elucidation of its taxonomic relationship to G. rhodochroa is the subject of the present study.

A total of 100 strains of Nocardia, Gordona, and Mycobacterium species (Fig. 1 and 2) was studied for a total of 105 characters. To the set of characters used previously (24), three enzyme tests, $\beta$-galactosidase activity (25), acid phosphatase activity (27), and semiquantitative catalase activity (14), were added, but 11 tests on the utilization of nitrogen compounds used previously were reduced to 4 in the present study. These four were the tests on utilization of benzamide, nicotinamide, $\mathrm{NaNO}_{3}$, and $\mathrm{NaNO}_{2}$ as the sole source of nitrogen. The reason for the reduction was indicated previously (24). Of the 105 characters tested, 91 were effective for differentiating the strains. Fourteen characters were ineffective: nine showed positive matches (gram positiveness; glycerol as carbon source; growth at $37 \mathrm{C}$; growth at $28 \mathrm{C}$; resistance to $0.0625 \mathrm{mg}$ of $\mathrm{NH}_{2} \mathrm{OH} \cdot \mathrm{HCl}$ per $\mathrm{ml}$; resistance to $0.1 \% \mathrm{NaNO}_{2}$ in Sauton agar; resistance to $0.5 \mathrm{mg}$ of sodium salicylate per $\mathrm{ml}$; resistance to $10 \mathrm{mg}$ of thiophene-2-carboxylic acid hydrazide per $\mathrm{ml}$; glucose as carbon source); five showed negative matches in all strains (malonamidase; raffinose as carbon source; acid formation from raffinose; nicotinamide as simultaneous nitrogen and carbon sources; photochromogenicity). The methods used were described previously $(1,12,14,18,19$, $21,24,26-28)$.

Similarity values (matching coefficient $=M$ value) between the strains were calculated by the following equation: $M$ value $=\left[n_{s} /\left(n_{s}+n_{d}\right)\right]$ $\times 100 \%$, where $n_{s}$ is the number of characters which show the same code symbols $(++$ or - -) and $n_{d}$ is the number of characters which show different code symbols $(+-)$. Clustering was made by the single-linkage method (17).

The results are shown in Fig. 1 and 2 as dendrograms. Probably due to the change of the characters used, three taxa, Nocardia, Gordona (rhodochrous group), and rapidly growing mycobacteria, were not so clearly separated as previously, but the three taxa could still be distinguished.

With the exception of $G$. auratiaca, all Gordona strains formed a cluster at the $90 \%$ level. All strains of $N$. rubra tested (M-1, C-1, M-103, M-122, M-191, and M-192) were incorporated into the Gordona cluster, five forming a new subcluster and only one (strain M-191) being incorporated into another subcluster with $G$. rubropertincta, $G$. rosea, and $G$. terrae. $G$. rubra, described in 1971 (22), is now a synonym of $G$. rubropertincta (23). The Gordona organisms were classified into five subgroups: (i) $N$. rubra; (ii) G. rhodochroa (strain ATCC 13808, named Rhodococcus rhodochrous Zopf [15, 29], belongs to this taxon [23, 24]); (iii) $G$. bron- 


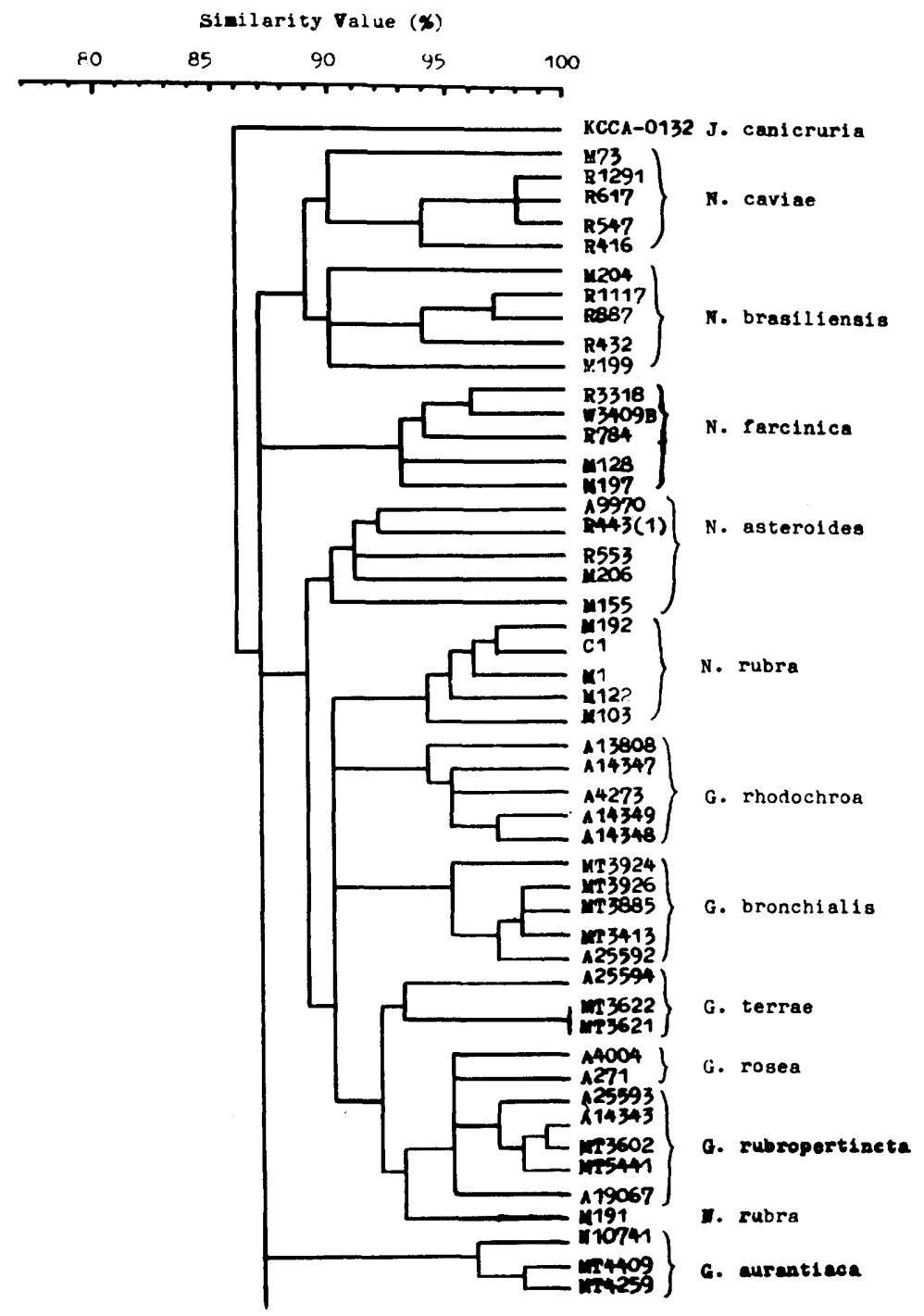

FIG. 1. Dendrogram of the relationships between rapidly growing mycobacteria, Gordona, and Nocardia. The strains bearing the initial code A were received from the American Type Culture Collection, Rockville, $M d$.; those bearing the code $N$ were from the National Collection of Type Cultures, London; those bearing the code $R$ (and $W$ ) were from Ruth $E$. Gordon, Institute of Microbiology, Rutgers State University, New Brunswick, N.J.; those bearing the codes $M$ and $C$ were from I. Uesaka, Kyoto University, Kyoto, Japan; and those bearing the code MT belonged to the collection of our laboratory. The strains received from I. Uesaka belonged originally to the collection of N.M. McClung, University of South Florida, Tampa. The type strain of Jensenia canicruria was received from A. Shimizu, Kaken Chemical Company, Tokyo, Japan (KCCAO132; Y. Okami; IMC; ATCC 11048; NCTC 8036).

chialis; (iv) G. rubropertincta, G. rosea, and $G$. terrae; and (v) G. aurantiaca.

The fourth subcluster could be divided into two subgroups, one consisting of $G$. rubropertincta and $G$. rosea and another consisting of $G$. terrae, at the $94 \%$ level. These three could previously be differentiated from each other (23,
24) but were lumped into one in the present study at the $92 \%$ level. The oldest specific epithet among these three is roseus (10).

In addition, four species of the genus Nocardia could be differentiated as different clusters $-N$. brasiliensis, $N$. caviae, $N$. farcinica (see Tsukamura [20]), and $N$. asteroides. The 

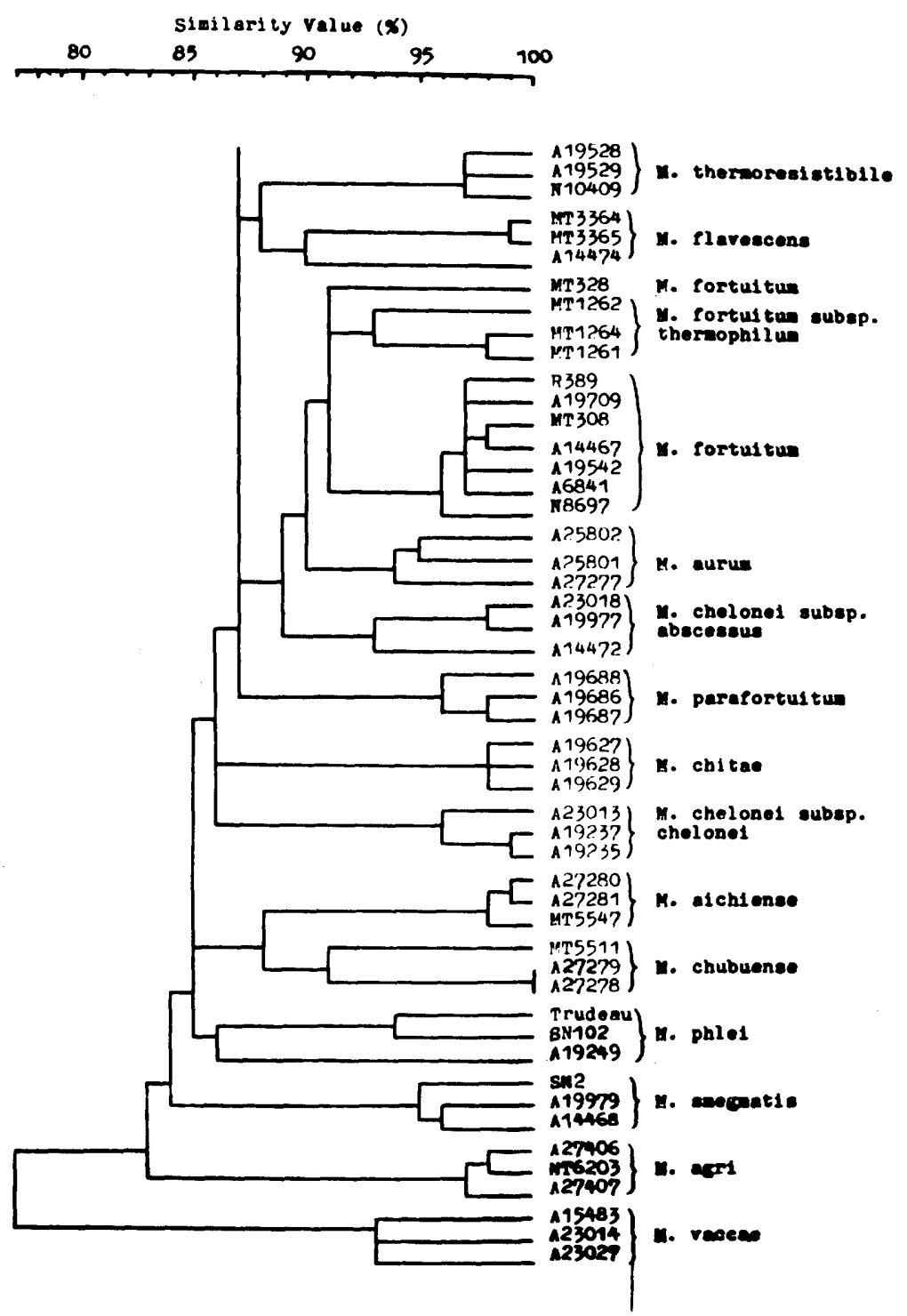

Fig. 2. Dendrogram of the relationships between rapidly growing mycobacteria, Gordona, and Nocardia (see legend to Fig. 1 for additional information).

following species of rapidly growing mycobacteria were differentiated from each other at the 90\% level as distinct clusters: $M$. thermoresistibile, $M$. flavescens, $M$. fortuitum, $M$. aurum, $M$. parafortuitum, $M$. chelone $i$ subsp. chelonei, $M$. chelonei subsp. abscessus, $M$. chitae, $M$. aichiense, $M$. chubuense, $M$. phlei, $M$. smegmatis, M. agri, M. vaccae. Previously, $M$. parafortuitum was reported as a synonym of $M$. vaccae (13), but these two organisms could be differentiated from each other in the present study.

Distinguishing characters for differentiating
Nocardia, Gordona (rhodochrous group), and rapidly growing mycobacteria are shown in Table 1. The table includes not only the data of the present study but also those of other studies. Characters useful for differentiating between the species of the genus Gordona are shown in Table 2.

Taxonomic position and nomenclature of N. rubra. It has been shown that the strains of $N$. rubra cluster at a high level with the rhodochrous and other organisms placed in the genus Gordona . 
TABLE 1. Distinguishing characters for differentiating between the taxa rapidly growing mycobacteria, Gordona and Nocardia

\begin{tabular}{|c|c|c|c|c|c|c|c|c|c|}
\hline \multirow{2}{*}{ Species } & \multirow{2}{*}{ No. ${ }^{a}$} & \multicolumn{8}{|c|}{ Percentage of strains showing positive reaction } \\
\hline & & AF & MYC & ARY & SUC & MAN & TMD & GAL & $\mathrm{NO}_{3}$ \\
\hline Nocardia brasiliensis & 7 & 0 & 100 & 0 & 14 & 0 & 0 & 100 & 0 \\
\hline N. caviae & 8 & 0 & 100 & 0 & 0 & 0 & 0 & 100 & 12 \\
\hline N. farcinica & 32 & 0 & 100 & 0 & 28 & 6 & 0 & 100 & 0 \\
\hline N. asteroides & 15 & 0 & 100 & 7 & 7 & 0 & 0 & 100 & 60 \\
\hline N. rubra & 5 & 0 & 100 & 0 & 100 & 0 & 0 & 0 & 100 \\
\hline Gordona bronchialis & 41 & 0 & 0 & 0 & 100 & 100 & 0 & 0 & 98 \\
\hline G. rhodochroa & 10 & 0 & 10 & 0 & 100 & 60 & 0 & 0 & 100 \\
\hline G. rosea-rubropertincta & 36 & 0 & 0 & 0 & 100 & 100 & 0 & 0 & 92 \\
\hline G. aurantiaca & 6 & 17 & 0 & 0 & 100 & 100 & 0 & 100 & 0 \\
\hline Mycobacterium thermoresistibile & 39 & 100 & 0 & 0 & 5 & 0 & 0 & 0 & 100 \\
\hline M. flavescens & 10 & 100 & 0 & 100 & 0 & 0 & 0 & 0 & 100 \\
\hline M. chitae & 7 & 100 & 0 & 100 & 0 & 0 & 0 & 0 & 100 \\
\hline M. agri & 31 & 100 & 0 & 100 & 0 & 100 & 23 & 100 & 97 \\
\hline M. chelonei subsp. chelonei & 20 & 100 & 0 & 100 & 0 & 100 & 0 & 100 & 0 \\
\hline M. chelonei subsp. abscessus & 24 & 100 & 0 & 100 & 33 & 50 & 92 & 96 & 25 \\
\hline$M$. fortuitun & 132 & 100 & 0 & 100 & 17 & 69 & 100 & 0 & 100 \\
\hline M. aurum & 18 & 100 & 0 & 100 & 6 & 100 & 100 & 11 & 67 \\
\hline M. parafortuitum & 6 & 100 & 0 & 100 & 17 & 100 & 100 & 0 & 83 \\
\hline$M$. aichiense & 8 & 100 & 0 & 100 & 0 & 100 & 0 & 0 & 0 \\
\hline M. chubuense & 15 & 100 & 0 & 100 & 100 & 100 & 100 & 7 & 100 \\
\hline M. vaccae & 12 & 100 & 0 & 100 & 83 & 25 & 0 & 0 & 0 \\
\hline M.phlei & 20 & 100 & 0 & 100 & 100 & 20 & 100 & 80 & 100 \\
\hline M. smegmatis & 24 & 100 & 0 & 100 & 96 & 100 & 100 & 83 & 100 \\
\hline
\end{tabular}

${ }^{a}$ Number of strains tested.

${ }^{b}$ Abbreviations: AF, strong acid-fastness; MYC, fragmenting mycelium; ARY, two week-arylsulfatase; SUC, sucrose as sole carbon source; MAN, acid from mannose; TMD, trimethylenediamine as simultaneous nitrogen and carbon sources; GAL, $\beta$-galactosidase; $\mathrm{NO}_{3}$, nitrate reduction (nitrite produced from nitrate).

Gordon and $\operatorname{Mihm}(9,10)$ were the first to differentiate the rhodochrous group from nocardiae. They named the taxon Mycobacterium rhodochrous. Later, Gordon (7) regarded it as an intermediate between Mycobacterium and Nocardia. Goodfellow and his associates $(5,6)$ were able to differentiate "Mycobacterium" rhodochrous from nocardiae by applying numerical methods to their data. Tsukamura (22) proposed the genus Gordona for these and other slightly acid-fast organisms from sputum and soil.

The evidence provided by this study indicates that the species $N$. rubra should be transferred to the genus Gordona in association with $G$. rhodochroa and other species.

This transfer would result in the combination $G$. rubra. However the name was once used for another organism, Gordona rubra Tsukamura (22), which was subsequently shown to be identical to Gordona rubropertincta, which name had priority. Consequently, a new specific epithet lentifragmenta is proposed under Rule 34b Note 2 of the Bacteriological Code, giving the new name Gordona lentifragmenta Tsukamura for those organisms previously known under the name Nocardia rubra (Kruse) Chalmers and Christopherson (see reference 20). The characters of the species are given below.

(i) Morphology. Usually occur as gram-positive, slightly acid-fast or non-acid-fast rods or coccoids; mycelia form at early stage of growth but later fragment into rods, short rods, and coccoids; form pinkish-pigmented, rough colonies on egg media and Sauton agar.

(ii) Biological. Growth occurs at $28 \mathrm{C}$ and $37 \mathrm{C}$, but not at $45 \mathrm{C}$; growth occurs at 3 days on egg media and Sauton agar; tolerant to $0.2 \%$ picric acid in Sauton agar; tolerant to $0.1 \%$ $\mathrm{NaNO}_{2}$ in Sauton agar; tolerant to $0.25 \mathrm{mg}$ of $\mathrm{NH}_{2} \mathrm{OH} \cdot \mathrm{HCl}$ per $\mathrm{ml}$ in Ogawa egg medium; tolerant to $0.5 \mathrm{mg}$ of $p$-nitrobenzoic acid per $\mathrm{ml}$ in Ogawa egg medium; tolerant to $1.0 \mathrm{mg}$ of sodium salicylate per $\mathrm{ml}$ in Ogawa egg medium; susceptible to $5 \mu \mathrm{g}$ of ethambutol per $\mathrm{ml}$ in Ogawa egg medium (Löwenstein-Jensen me- 
TABLE 2. Characters useful for differentiating the species of Gordona

\begin{tabular}{|c|c|c|c|c|c|c|}
\hline \multirow[b]{2}{*}{ Character } & \multicolumn{6}{|c|}{ Percentage of strains showing positive reaction } \\
\hline & N. rubra & $\begin{array}{l}\text { G. bron- } \\
\text { chialis }\end{array}$ & $\begin{array}{l}\text { G. rho- } \\
\text { dochroa }\end{array}$ & G. terrae & $\begin{array}{l}\text { G. rosea- } \\
\text { rubroper- } \\
\quad \text { tincta }\end{array}$ & $\begin{array}{c}G . \\
\text { auran- } \\
\text { tiaca }\end{array}$ \\
\hline Acid phosphatase & 0 & 90 & 30 & 0 & 0 & 0 \\
\hline$\alpha$-Esterase & 0 & 0 & 0 & 90 & 12 & 0 \\
\hline Tween hydrolysis (14 days) & 0 & 0 & $100^{a}$ & 0 & 0 & 100 \\
\hline \multicolumn{7}{|c|}{$\begin{array}{l}\text { Utilization as simultaneous nitrogen } \\
\text { and carbon sources }\end{array}$} \\
\hline Acetamide & 100 & 98 & 0 & 0 & 0 & 100 \\
\hline Monoethanolamine & 80 & 0 & 0 & 95 & 100 & 100 \\
\hline \multicolumn{7}{|l|}{ Acid from: } \\
\hline Galactose & 0 & 0 & 0 & 0 & 0 & 100 \\
\hline Xylose & 0 & 0 & 0 & 0 & 0 & 100 \\
\hline Rhamnose & 0 & 0 & 0 & 100 & 0 & 0 \\
\hline Trehalose & 0 & 98 & 0 & 100 & 70 & 100 \\
\hline Inositol & 0 & 98 & 0 & 0 & 0 & 100 \\
\hline Mannitol & 100 & 24 & 0 & 100 & 100 & 100 \\
\hline Sorbitol & 100 & 0 & 0 & 100 & 100 & 100 \\
\hline Benzoate as sole carbon source & 80 & 32 & 60 & 5 & 100 & 0 \\
\hline Malonate as sole carbon source & 60 & 0 & 0 & 0 & 0 & 0 \\
\hline Acetamidase & 100 & 98 & 20 & 0 & 0 & 100 \\
\hline Nicotinamidase & 60 & 86 & 0 & 80 & 20 & 100 \\
\hline Pyrazinamidase & 60 & 83 & 0 & 80 & 20 & 100 \\
\hline Allantoinase & 0 & 0 & 0 & 95 & 100 & 100 \\
\hline No. of strains tested & 5 & 41 & 10 & 20 & 17 & 6 \\
\hline
\end{tabular}

${ }^{a}$ Weakly positive.

dium may be substituted for Ogawa egg medium).

(iii) Enzyme activities. Tween not hydrolyzed at 14 days; $\alpha$ - and $\beta$-esterase activities not shown; $\beta$-galactosidase negative; catalase negative; nitrate reduced to nitrite; arylsulfatase activity not shown at 2 weeks; acetamidase activity shown but other amidase activities (Bönicke's series) not shown.

(iv) Nutritional requirements. Glucose, mannose, sucrose, $n$-propanol, $n$-butanol, isobutanol, propylene glycol, mannitol, and sorbitol utilized as carbon source in the presence of ammoniacal nitrogen, but galactose, arabinose, xylose, rhamnose, trehalose and inositol not utilized; acid formed from glucose, but acid not formed from mannose; acetate, citrate, succinate, malate, pyruvate, malonate, and fumarate utilized as carbon source; glutamate, glucosamine, acetamide, and monoethanolamine utilized, but serine, benzamide and trimethylene diamine not utilized as simultaneous nitrogen and carbon sources.

Transfer of some $N$. rubra strains to the rhodochrous group was reported recently also by other investigators, although the definition as a species was not yet made. Bradley (2) divided the rhodochrous complex into two subgroups; one consisted of $N$. corallina and $N$. rubra and the other consisted of $N$. erythropolis. These two groups differed in their guanine plus cytosine content. Bradley and Huitron (3) observed that deoxyribonucleic acid (DNA) from a strain of $N$. coeliaca annealed extensively with DNA from $N$. erythropolis references, but DNA from a strain of $N$. globerula did not anneal appreciably with the $N$. erythropolis references. Ridell (16) studied the serological relationsitips between 125 strains of Nocardia and Mycobacterium by means of the comparative immunodiffusion technique and observed that eight strains, either designated $N$. corallina, $N$. rubra or $M$. rhodochrous, revealed a close relationship with the $N$. corallina reference strain. She also observed that strains designated $N$. rubra were heterogenous. Gordon et al. (8) reported that the type strain of $N$. coeliaca is a member of the rhodochrous group.

It was found recently that the test of $\beta$-galactosidase activity is a useful tool for differentiating Gordona organisms from nocardiae (25). The gordonae showed a negative reaction and the nocardiae a positive one. Strains identified previously as $N$. rubra (20) showed different reactions. Strains $\mathrm{M}-1$ and $\mathrm{C}-1$ reveived as $N$. rubra, strain M-103 received as $N$. minima, 
strain M-192 received as $N$. lutea, strain M-122 received as $N$. coeliaca, and strain M-191 received as $N$. rubropertincta showed a negative reaction, and all, except for the strain, were incorporated into Gordona lentifragmenta Tsukamura. Strain M-75 received as $N$. globerula, strain M-79 received as $N$. convoluta, and strain M-6 received as $N$. polychromogenes showed a positive reaction. The latter three strains were not included as subjects of the present study.

We thank V. B. D. Skerman, Department of Microbiology, University of Queensland, Brisbane, Australia, for his kind revision of the manuscript.

\section{REPRINT REQUESTS}

Address reprint requests to: Dr. M. Tsukamura, National Sanatorium Chubu Chest Hospital, Obu, Aichi, Japan 474.

\section{LITERATURE CITED}

1. Bönicke, R. 1962. L'identification des mycobactéries à l' aide de méthodes biochimiques. Bull. Union Int. Tuberc. 32:13-76.

2. Bradley, S. G. 1971. Criteria for definition of Mycobacterium, Nocardia and the Rhodochrous group. Advancing Frontiers of Plant Sciences 28:349- 362.

3. Bradley, S. G., and M. E. Huitron. 1973. Genetic homologies among nocardiae. Dev. Ind. Microbiol. 14:189199 .

4. Buchanan, R. E., J. G. Holt, and E. F. Lessel, Jr. (ed.). 1966. Index Bergeyana. The Williams and Wilkins Co., Baltimore.

5. Goodfellow, M. 1971. Numerical taxonomy of some nocardioform bacteria. J. Gen. Microbiol. 69:33-80.

6. Goodfellow, M., A. Fleming, and M. J. Sackin. 1972. Numerical classification of "Mycobacterium" rhodochrous and Runyon's group IV bacteria. Int. J. Syst. Bacteriol. 22:81-98.

7. Gordon, R. E. 1966. Some strains in search of a genusCorynebacterium, Mycobacterium, Nocardia or what? J. Gen. Microbiol. 43:329-343.

8. Gordon, R. E., D. A. Barnett, J. E. Handerham, and C. H. Pang, 1974. Nocardia coeliaca, Nocardia autotroph$i c a$, and the Nocardia strain. Int. J. Syst. Bacteriol. 24:54-63.

9. Gordon, R. E., and J. M. Mihm. 1957. A comparative study of some strains received as nocardiae. J. Bacteriol. 21:736-748

10. Gordon, R. E., and J. M. Mihm. 1959. A comparison of four species of mycobacteria. J. Gen. Microbiol. $21: 736: 748$

11. Grotenfelt, G. 1889. Studien über die Zersetzung der Milch. Fortschr. Med. 7:41-46 (cited from Index Bergeyana)
12. Käppler, W. 1965. Acetyl-Naphthylamin-Esterasen-Aktivität von Mykobakterien. Beitr. Klin. Tuberk. 130:1-4.

13. Kubica, G. P., I. Baess, R. E. Gordon, P. A. Jenkins, J. B. G. Kwapinski, C. McDurmont, S. R. Pattyn, H. Saito, V. Silcox, J. L. Stanford, K. Takeya, and M. Tsukamura. 1972. A co-operative numerical analysis of rapidly growing mycobacteria. J. Gen. Microbiol. 73:55-70.

14. Kubica, G. P., W. D. Jones, Jr., V. D. Abbott, R. E. Beam, J. O. Kilburn, and J. C. Cater, Jr. 1966. Differential identification of mycobacteria. I. Tests on catalase activity. Am. Rev. Resp. Dis. 94:400-405.

15. Overbeck, A. 1891. Zur Kenntnis der Fettfarbstoff-Produktion bei Spaltpilzen. Nova Acta Leopold. 55:399416 (cited from Index Bergeyana).

16. Ridell, M. 1974. Serological study of nocardiae and mycobacteria by using "Mycobacterium" pellegrino and Nocardia corallina precipitation reference systems. Int. J. Syst. Bacteriol. 24:64-72.

17. Sokal, R. R., and P. H. A. Sneath. 1963. Principles of numerical taxonomy. W. H. Freeman, San Francisco.

18. Tsukamura, M. 1966. Adansonian classification of mycobacteria. J. Gen. Microbiol. 45:253-273.

19. Tsukamura, M. 1967. Identification of mycobacteria Tubercle 48:311-338.

20. Tsukamura, M. 1969. Numerical taxonomy of the genus Nocardia. J. Gen. Microbiol. 56:265-287.

21. Tsukamura, M. 1969. Identification of Group II scotochromogens and Group III nonphotochromogens of mycobacteria. Tubercle 50:51-60.

22. Tsukamura, M. 1971. Proposal of a new genus, Gordona, for slightly acid-fast organisms occurring in sputa of patients with pulmonary disease and in soil. J. Gen. Microbiol. 68:15-26.

23. Tsukamura, M. 1973. A taxonomic study of strains received as "Mycobacterium" rhodochrous. Description of Gordona rhodochroa (Zopf; Overbeck; Gordon et Mihm) Tsukamura comb. nov. Jpn. J. Microbiol. 17:189-197.

24. Tsukamura, M. 1974. A further numerical taxonomic study of the Rhodochrous group. Jpn. J. Microbiol. 18:37-44.

25. Tsukamura, M. 1974. Differentiation of the Mycobacterium' rhodochrous-group from nocardiae by $\beta$-galactosidase activity. J. Gen. Microbiol. 80:553-555.

26. Tsukamura, M., and S. Mizuno. 1971. Differentiation of Mycobacterium avium and Mycobacterium intracellulare by utilization of butanols as carbon source. Kekkaku 46:197-202.

27. Tsukamura, M., S. Mizuno, H. Murata, and T. Oshima. 1974. Acid phosphatase activity of mycobacteria. Iryo 28:11-14.

28. Wayne, L. G., J. R. Doubek, and R. L. Russell. 1964. Classification and identification of mycobacteria. I. Tests employing Tween 80 as substrate. Am. Rev. Resp. Dis. 90:588-597.

29. Zopf, W. 1891. Ueber Ausscheidung von Fettfarbstoffen (Lipochromen) seitens gewisser Spaltpilze. Ber. Dtsch. Bot. Ges. 9:22-28 (cited from Index Bergey. ana). 